\title{
Jarak Pisah Sudut Puncak Difraksi Antara Bidang (hkl) Utama Sebagai Indikator Keorthorhombikan Struktur Kisi Kristal Fase $\mathrm{GdBa}_{2} \mathrm{Cu}_{3} \mathrm{O}_{7-\delta}$
}

\author{
The Separation Distance of the Diffraction Peak Angle between \\ Main Planes (hkl) As an Indicator of the Orthorhombicity of the \\ $\mathrm{GdBa}_{2} \mathrm{Cu}_{3} \mathrm{O}_{7-\delta}$ Phase Crystal Lattice Structure
}

\author{
I Komang Wahyu Surya Permana ${ }^{1}$, Made Sumadiyasa ${ }^{1}$, Windarjoto ${ }^{1}$ \\ ${ }^{1}$ Program Studi Fisika, Fakultas Matematika dan Ilmu Pengetahuan Alam, Universitas Udayana, \\ Kampus Bukit Jimbaran, Badung, Bali, Indonesia 80361 \\ Email: wahyusuryapermana98@gmail.com, *sumadiyasa64@gmail.com, windaryoto@unud.ac.id
}

\begin{abstract}
Abstrak - Keothorhombikan suatu struktur kisi kristal ditunjukkan oleh adanya perbedaan nilai parameter kisi a, b dan c. Penelitian ini bertujuan untuk menunjukkan bahwa nilai jarak pisah antara sudut puncak difraksi kedua bidang ( $h k l)$ yang paling dekat sama dengan nilai orthorhombisitas struktur kristal pada fase $\mathrm{GdBa}_{2} \mathrm{Cu}_{3} \mathrm{O}_{7-\delta}$. Untuk tujuan tersebut, dalam penelitian ini telah disintesis senyawa $\mathrm{Gd}_{0,85} \mathrm{La}_{0,15} \mathrm{Ba}_{2-x} \mathrm{Sr}_{x} \mathrm{Cu}_{3} \mathrm{O}_{7-\delta}$ dengan variasi $x=0,00,0,05,0,10,0,20,0,30$ dan 0,50. Sampel disintesis menggunakan metode reaksi padatan dengan pencampuran basah, disintering pada suhu $900{ }^{\circ} \mathrm{C}$ selama 12 jam. Dari hasil analisis spektrum XRD dengan software Match-3 dan Rietica didapatkan bahwa, dengan bertambahnya kandungan Sr pola perubahan nilai jarak pisah sudut puncak difraksi bidang ( $\mathrm{hkl}$ ) terdekat hasil pengukuran dan perhitungan sama dengan pola perubahan nilai keorthorhombikan. Hasil pengukuran dan perhitungan nilai jarak pisah antara sudut puncak difraksi untuk bidang (020) dan (200) hampir sama dengan sepersepuluh dari nilai keorthorhombikan. Dengan demikian, nilai jarak pisah antara sudut puncak difraksi dari dua bidang ( $h k l)$ terdekat dapat digunakan sebagai indikator keorthorhombikan struktur kristal fase $\mathrm{GdBa}_{2} \mathrm{Cu}_{3} \mathrm{O}_{7-\delta}$.
\end{abstract}

Kata kunci: Senyawa $\mathrm{Gd}_{0,85} \mathrm{La}_{0,15} \mathrm{Ba}_{2-x} \mathrm{Sr}_{x} \mathrm{Cu}_{3} \mathrm{O}_{7-\delta}$, jarak pisah puncak difraksi $\triangle 2 \theta$, orthorhombic, tetragonal, orthorhombic splitting (OS), parameter kisi a dan b.

\begin{abstract}
The orthorombicity of a crystal lattice structure is indicated by the difference in lattice parameter values $a, b$ and $c$. This study aims to show that the split distance value between the angles of the diffraction peaks of the two planes $(\mathrm{hkl})$ closest is the same as the orthorombicity value crystal structure on the GdBa2Cu3O7- $\delta$ phase. For this purpose, in this study, a compound $G_{0,85} L a_{0,15} B a_{2-}$ ${ }_{x} \mathrm{Sr}_{x} \mathrm{Cu}_{3} \mathrm{O}_{7-\delta}$ has been synthesized with variations of $x=0.00,0.05,0.10,0.20,0.30$ and 0.50. Samples were synthesized using a solid reaction method with wet mixing, sintered at a temperature of $900^{\circ} \mathrm{C}$ for 12 hours. From the results of XRD spectrum analysis with Match-3 and Rietica software, it is found that by the increasing the content of Sr the pattern of changes in the value of the split distance the angles of the diffraction peaks of $(\mathrm{hkl})$ planes closest, the measurement and calculation results are the same with the changing pattern of the orthorombicity value. The measurement and calculation results, the split distance value between the diffraction peaks angle for the plane of (020) and (200) is almost equal to one-tenth of the orthorombicity value. Thus, the split distance value between the angles of the diffraction peaks of the two (hkl) planes closest can be used as an indicator of the orthorombicity a $\mathrm{GdBa}_{2} \mathrm{Cu}_{3} \mathrm{O}_{7-\delta}$ phase crystal structure.
\end{abstract}

Key word: $G d_{0,85} \mathrm{La}_{0,15} \mathrm{Ba}_{2-x} \mathrm{Sr}_{x} \mathrm{Cu}_{3} \mathrm{O}_{7-\delta}$ compound, diffraction peak separation distance $42 \theta$, orthorhombic, tetragonal, orthorhombic splitting (OS), lattice parameters $a$ and $b$.

\section{Pendahuluan}

Semenjak ditemukannya superkonduktor fase YBCO telah banyak dilakukan penelitian baik aspek metode sintesis, sifat-sifat fisika, kimia, maupun aplikasinya. Dalam penelitian-penelitian tersebut sampel dikarakterisasi XRD, Dari karakterisasi XRD dilakukan analisis sudut dan intensitas dari puncak-puncak (peaks) difraksi dari suatu bidang difraksi Bragg (hkl) karakteristik dari suatu kristal. Pada tahun 1987 Aravinda dkk. [1] menunjukkan bahwa superkonduktor fase YBCO memiliki dua fase, yaitu fase non- 
superkonduktif dengan struktur unit sel tetragonal (space group P4m2) dan fase superkonduktif dengan struktur unit sel orthorhombik (space group Pmmm) seperti diperlihatkan pada Gambar 1 [2].

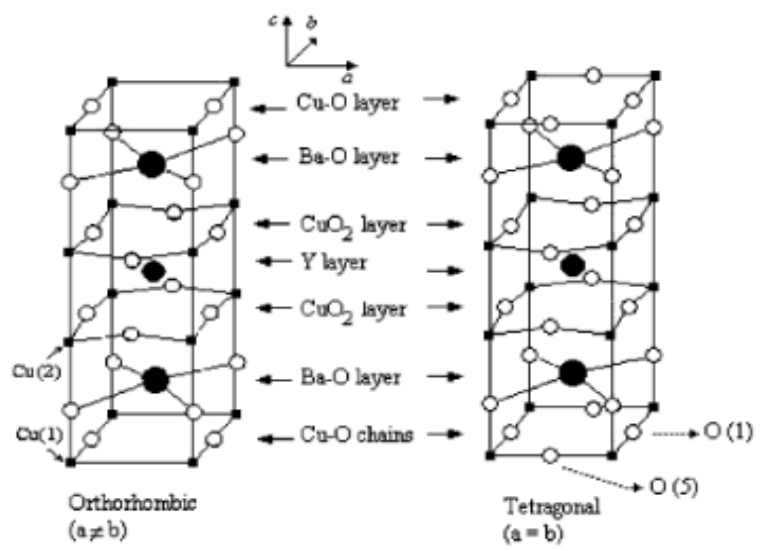

Gambar 1. Struktur unit sel kristal $\mathrm{YBa}_{2} \mathrm{Cu}_{3} \mathrm{O}_{7-\delta}$ : (a) orthorhombik dimana posisi $\mathrm{O}(5)$ kosong, (b) tetragonal [2].

Sebagaimana diperlihatkan pada Gambar 1, struktur unit sel kristal $\mathrm{YBa}_{2} \mathrm{Cu}_{3} \mathrm{O}_{7-\delta}$ terdiri atas 7 lapisan (layer) yang ditumpuk dengan urutan $-\mathrm{CuO}_{\mathrm{x}}-\mathrm{BaO}-\mathrm{CuO}_{2}-\mathrm{Y}-\mathrm{CuO}_{2}-\mathrm{BaO}-\mathrm{CuO}_{\mathrm{x}}$. Pada lapisan $\mathrm{CuO}_{x}$ setiap atom $\mathrm{Cu}$ dikoordinasikan oleh empat atom oksigen, sedangkan pada lapisan $\mathrm{CuO}_{2}$ setiap atom $\mathrm{Cu}$ dikelilingi oleh lima atom oksigen. Fase non-superkonduktif memiliki atom oksigen terdistribusi pada situs $\mathrm{O}(1)$ dan $\mathrm{O}(5)$, sehingga strukturnya adalah tetragonal dengan grup ruang adalah $\mathrm{P} 4 / \mathrm{Pmmm}$ dimana posisi $\mathrm{O}(1)$ dan $\mathrm{O}(5)$ sama-sama ditempati oleh oksigen. Pada keadaan superkonduktif posisi $\mathrm{O}(5)$ dalam keadaan kosong sementara posisi $\mathrm{O}(1)$ terisi hampir penuh bahkan penuh sehingga struktur kisi menjadi orthorhombik dengan grup ruang Pmmm. Pada fase $\mathrm{GdBa}_{2} \mathrm{Cu}_{3} \mathrm{O}_{7-\delta}$ terjadi transisi struktur tetragonal-ortorombik pada kandungan oksigen antara 6,75 - 6,76, sedangkan pada fase $\mathrm{YBa}_{2} \mathrm{Cu}_{3} \mathrm{O}_{7-\delta}$ antara 6,47 - 6,49 [3]. Perubahan struktur kisi tersebut sering dihubungkan dengan adanya perubahan penempatan oksigen terutama pada posisi $\mathrm{O}(1)$ dan (O5).

Struktur kristal dapat diperoleh dari karakterisasi XRD. Orthorhombik atau tetragonalnya kisi kristal dari superkonduktor fase $\mathrm{YBa}_{2} \mathrm{Cu}_{3} \mathrm{O}_{7-\delta}$ dapat dilihat dari adanya pemecahan (splitting) suatu puncak difraksi dari suatu bidang (hkl) pada spektrum difraksi (difraktogram) [1, 4]. Demikian halnya pada fase $\mathrm{NdBa}_{2} \mathrm{Cu}_{3} \mathrm{O}_{7-\delta}$, Yosefov et al. pada 1997 menunjukkan bahwa keadaan orthorhombik atau tetragonalnya struktur kisi kristal dapat dilihat dari adanya pemecahan suatu puncak utama pada spektrum difraksi [5].

Pada artikel ini dijelaskan bagaimana keorthorhombikan (orthorhombicity) unit sel dapat ditunjukkan dari pengukuran dan perhitungan jarak pisah sudut antara dua puncak difraksi utama pada spektrum difraksi fase $\mathrm{GdBa}_{2} \mathrm{Cu}_{3} \mathrm{O}_{7-\delta}$. Untuk itu telah dibuat sampel dari senyawa $\mathrm{Gd}_{0.85} \mathrm{La}_{0.15} \mathrm{Ba}_{2-\mathrm{x}} \mathrm{Sr}_{\mathrm{x}} \mathrm{Cu}_{3} \mathrm{O}_{7-\delta}$ dengan variasi $\mathrm{x}=0,00,0,05,0,10,0,20,0,30$ dan 0,50 [8]. Karena besar jari-jari ionik $\mathrm{Ba}^{2+}>$ jari-jari ionik $\mathrm{Sr}^{2+}$ yaitu masing-masing adalah 149 dan 132 picometer maka sangat memungkinkan terjadinya perubahan struktur unit sel dan terjadi perubahan keorthorhombikan seiring dengan bertambahnya kandungan Sr. Sebagai akibatnya, terjadi perubahan pola puncak-puncak difraksi pada difraktogram hasil karakterisasi XRD nya.

\section{Studi Pustaka}

Gambar 2 memperlihatkan difraktogram dari hasil karakterisasi XRD fase $\mathrm{YBa}_{2} \mathrm{Cu}_{3} \mathrm{O}_{7-\delta}$ untuk struktur orthorhombik dan tetragonal. Tampak bahwa difraktogram kedua fase adalah berbeda. Pada pola difraksi orthorhombik terjadi redistribusi intensitas puncak pada sudut sekitar $2 \theta=32,5,47,58$ dan $68^{\circ}$ dan pemisahan puncak difraksi dalam kasus orthorhombik, misalnya pada bidang (012) dan (102) [1]. Chen, et al. pada 1987 [4] mengungkapkan bahwa terdapat dua fase orthorhombik, yaitu pertama, orthorhombik I ditandai oleh terpisahnya puncak difraksi bidang (200) dan (020) yang mana berimpitan dengan puncak difraksi bidang (006), terpisahnya puncak difraksi antara bidang (013) dan (103) yang mana berimpitan dengan puncak difraksi dari bidang (110). Kedua, orthorhombik II ditandai oleh terpisahnya puncakpuncak difraksi dari bidang (200), (020) dan (006), antara bidang (013), (103) dan (110). Sedangkan, fase tetragonal ditandai oleh berimpitannya puncak-puncak difraksi dari bidang (013) dan (103), bidang (200) 
dan (020). Sementara itu, puncak difraksi dari bidang (006) dan (110) masing-masing terpisah dari puncak difraksi bidang (020) dan (013).

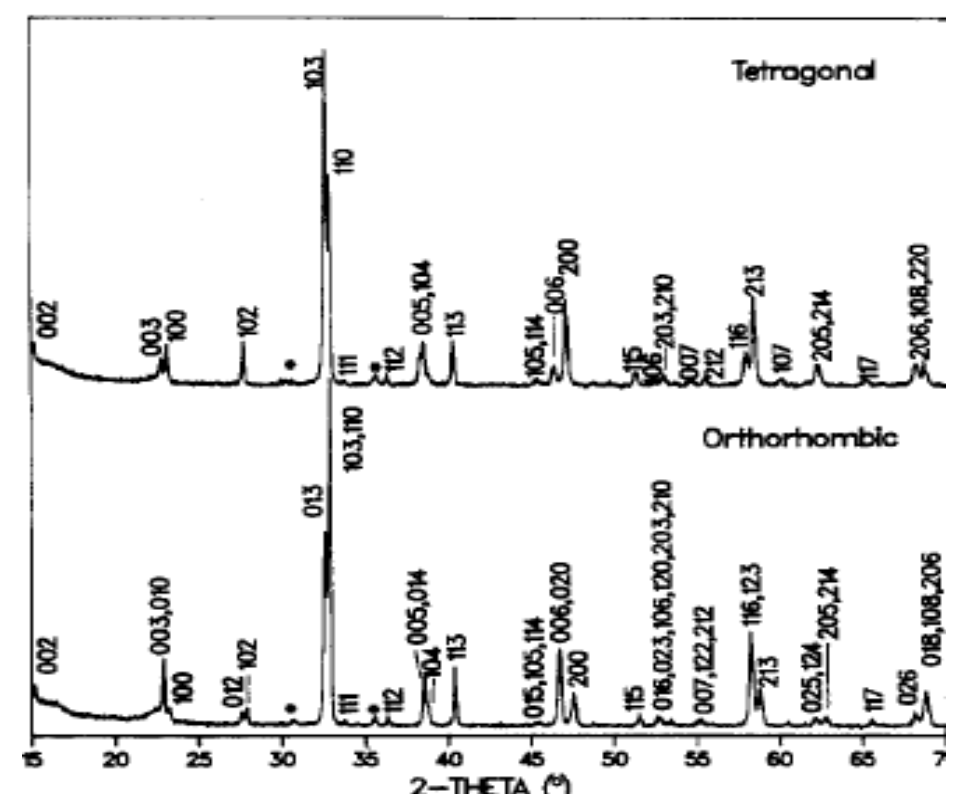

Gambar 2. Pola spektrum XRD dari struktur orthorhombik (bawah) dan tetragonal (atas) dari fase $\mathrm{YBa}_{2} \mathrm{Cu}_{3} \mathrm{O}_{7-\delta}[1]$.

Hal serupa dengan fase $\mathrm{YBa}_{2} \mathrm{Cu}_{3} \mathrm{O}_{7-\delta}$ juga diperlihatkan oleh superkonduktor sistem NdBCO [4], puncak-puncak difraksi utama pada spektrum difraksi. Bidang hkl yang menunjukkan perubahan terhadap parameter kisi kristal adalah bidang (013) dan (103) pada sudut puncak difraksi $2 \theta$ antara 32$32,8^{\circ}$, bidang (020) dan (200) pada pada sudut puncak difraksi $2 \theta$ antara 46-47,3 $3^{\circ}$, dan bidang (123) dan (213) pada sudut puncak difraksi $2 \theta$ antara $57,5-58,5^{\circ}$. Pemisahan puncak difraksi dari dua bidang (hkl) menunjukkan perubahan keorthorombikan unit sel Nd-123 $\left(\mathrm{YBa}_{2} \mathrm{Cu}_{3} \mathrm{O}_{7}-\delta\right)$. Setiap pasangan puncak difraksi di atas disertai oleh puncak tambahan, masing-masing puncak difraksi dari bidang (110), (006) dan (116).

Pola spektrum difraksi dari superkonduktor fase $\mathrm{RBa}_{2} \mathrm{Cu}_{3} \mathrm{O}_{7-\delta}(\mathrm{R}=\mathrm{Nd}, \mathrm{Sm}, \mathrm{Gd}, \mathrm{Y}, \mathrm{Ho}$, dan Er) dimana $\delta$ adalah parameter penyimpangan oksigen dengan nilai antara 0 sampai dengan 1 secara umum adalah serupa [3]. Adanya perubahan fase dari fase dengan struktur orthorhombik menjadi tetragonal, perubahan yang paling menonjol adalah perubahan bentuk dan posisi puncak difraksi pada lima daerah sudut Bragg $2 \theta$ utama, yaitu : antara $32^{\circ}$ sampai $33^{\circ}, 38^{\circ}$ sampai $39^{\circ}, 45^{\circ}$ sampai $49^{\circ}, 57^{\circ}$ sampai $60^{\circ}$, dan $68^{\circ}$ sampai $70^{\circ}$.

Perubahan struktur dari orthorhombik ke arah tetragonal sering diungkapkan sebagai destruksi keorthorhobikan. Ada beberapa formula untuk menyatakan destruksi keorthorhombikan tetapi pada intinya sama, yaitu dinyatakan dalam bentuk perbandingan perbedaan antara panjang parameter kisi $a$ dan $b$ dengan jumlah dari panjang parameter bersangkutan [5-7], bedanya hanya pada faktor pengalinya, tergantung pada besar atau kecilnya perbandingan tersebut. Sebagaimana dirumuskan oleh Yossefov et al. 1997 [5] dalam bentuk orthorhombic splitting (OS)

$$
O S=\frac{a-b}{a+b} \times 1000
$$

Yossefov et al. pada 1997 juga menunjukkan bahwa orthorhombik atau tetragonalnya struktur kisi secara dini dapat diverifikasi dari terpisah atau tidaknya puncak-puncak difraksi utama pada spekrum difraksi. Jarak pisah sudut $2 \theta$ antara puncak difraksi dari dua bidang (hkl) dapat diukur langsung dari difraktogram $\left(D^{9}\right)$ atau dihitung. Jarak pisah sudut $2 \theta$ antara puncak difraksi bidang (200) dan (020) dihitung dengan menggunakan persamaan (2) [5],

$$
\Delta 2 \theta=2[\arcsin (\lambda / b)-\arcsin (\lambda / a)\rfloor
$$


Jarak pisah sudut $2 \theta$ antara puncak difraksi dari dua bidang (103) dan (013), (213) dan (123) dapat dihitung dengan menggunakan persamaan (3) dan (4),

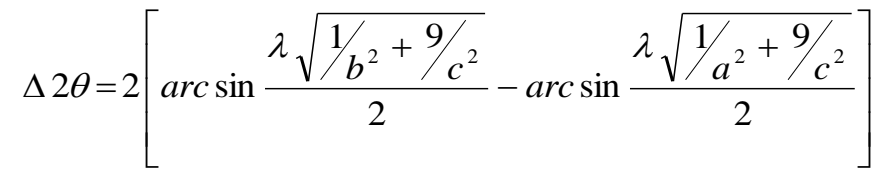

$$
\begin{aligned}
& \Delta 2 \theta=2\left[\arcsin \frac{\lambda \sqrt{4 / a^{2}+1 / b^{2}+9 / c^{2}}}{2}-\arcsin \frac{\lambda \sqrt{1 / a^{2}+4 / b^{2}+9 / c^{2}}}{2}\right]
\end{aligned}
$$

dengan $\Delta 2 \theta=$ jarak pisah sudut $2 \theta$ antara dua puncak difraksi dari dua bidang hkl; $\lambda=$ panjang gelombang sinar-x $(\AA)$ yang digunakan; $a, b$ dan $c=$ parameter kisi $(\AA)$. Karena pemisahan dua puncak difraksi berhubungan dengan orthorhombik atau tetragonalnya struktur unit sel maka besarnya jarak pisah sudut $2 \theta$ antara puncak difraksi dari dua bidang (hkl) akan dapat digunakan sebagai indikator keorthorombikan.

\section{Metode Penelitian}

Sampel superkonduktor sistem GBCO-123 senyawa fase $\mathrm{Gd}_{0.85} \mathrm{La}_{0.15} \mathrm{Ba}_{2-\mathrm{x}} \mathrm{Sr}_{\mathrm{x}} \mathrm{Cu}_{3} \mathrm{O}_{7-\delta}$ dengan variasi $\mathrm{x}=$ $0,00,0,05,0,10,0,20,0,30$ dan 0,50 disintesis menggunakan metode reaksi padatan dengan pencampuran basah [8]. Bahan awal untuk sintesis senyawa fase $\mathrm{Gd}_{0.85} \mathrm{La}_{0.15} \mathrm{Ba}_{2-\mathrm{x}} \mathrm{Sr}_{\mathrm{x}} \mathrm{Cu}_{3} \mathrm{O}_{7-\delta}$ adalah serbuk $\mathrm{Gd}_{2} \mathrm{O}_{3}, \mathrm{La}_{2} \mathrm{O}_{3}, \mathrm{BaO}$ dan $\mathrm{CuO}$ masing-masing dengan kemurnian 99,9\%. Semua bahan yang telah ditimbang sesuai dengan komposisi variasi x dilarutkan di dalam $\mathrm{HNO}_{3}$. Larutan diaduk pada hot-plate magnetic stirrer. Sambil diaduk larutan dipanaskan pada suhu $250^{\circ} \mathrm{C}$ sampai terbentuk gel. Gel dikeringkan pada suhu $300^{\circ} \mathrm{C}$ selama 6 jam, kemudian sampel yang sudah kering digerus di dalam mortar. Serbuk yang dihasilkan dipanaskan (dikalsinasi) pada suhu $400^{\circ} \mathrm{C}$ selama 2 jam, kemudian dilanjutkan dengan pemanasan pada suhu $500^{\circ} \mathrm{C}$ selama 2 jam dan pada suhu $600^{\circ} \mathrm{C}$ selama 6 jam. Setelah hasil kalsinasi dingin dilakukan penggerusan di dalam mortar, kemudian dipanaskan pada suhu $900^{\circ} \mathrm{C}$ dalam tungku selama 15 menit. Hasil pemanasan tersebut digerus kemudian dibuat menjadi pelet untuk disintering pada suhu $900^{\circ} \mathrm{C}$ selama 12 jam.

Sampel dikarakterisasi dengan difraksi sinar-X (difraktometer XPERT-PRO) dengan radiasi CuK $\alpha$ $(\lambda=1,5425 \AA)$. Dilakukan pengukuran sudut difraksi pada rentang $2 \theta=10^{\circ}$ hingga $80^{\circ}$ dan software Match-3 digunakan untuk mengidentifikasi keberadaan puncak-puncak dari fase GBCO-123 dan fase pengotornya [9]. Parameter kisi $a, b$ dan $c$ dari unit sel dihitung dengan metode Rietveld menggunakan software Rietica. Dilakukan perhitungan keorthorhombikan dengan menggunakan persamaan (1) dan jarak pisah antara dua puncak difraksi dari bidang (hkl) terdekat dengan menggunakan persamaan (2) (4).

\section{Hasil Dan Pembahasan}

\subsection{Hasil XRD}

Dari hasil analisis dengan menggunakan software Match-3 dapat ditandai posisi puncak-puncak difraksi dari bidang (hkl) utama dari fase GBCO-123 untuk senyawa $\mathrm{Gd}_{0,85} \mathrm{La}_{0,15} \mathrm{Ba}_{2-\mathrm{x}} \mathrm{Sr}_{\mathrm{x}} \mathrm{Cu}_{3} \mathrm{O}_{7-\delta}$. seperti diperlihatkan pada Gambar 3 - Gambar 5. Dari gambar tersebut dapat dilihat tiga daerah sudut difraksi bidang (hkl), yaitu pada sudut $2 \theta$ antara $32^{\circ}-32,8^{\circ}$ adalah difraksi dari bidang (213) dan (123), pada sudut $2 \theta$ antara $46^{\circ}-47,3^{\circ}$ adalah difraksi dari bidang (020) dan (200) dan pada sudut $2 \theta$ antara $57,5^{\circ}-58,5^{\circ}$ adalah difraksi dari bidang (123) dan (213). Tampak terdapat pemisahan antara puncak-puncak difraksi yang mana dapat diukur secara manual. 


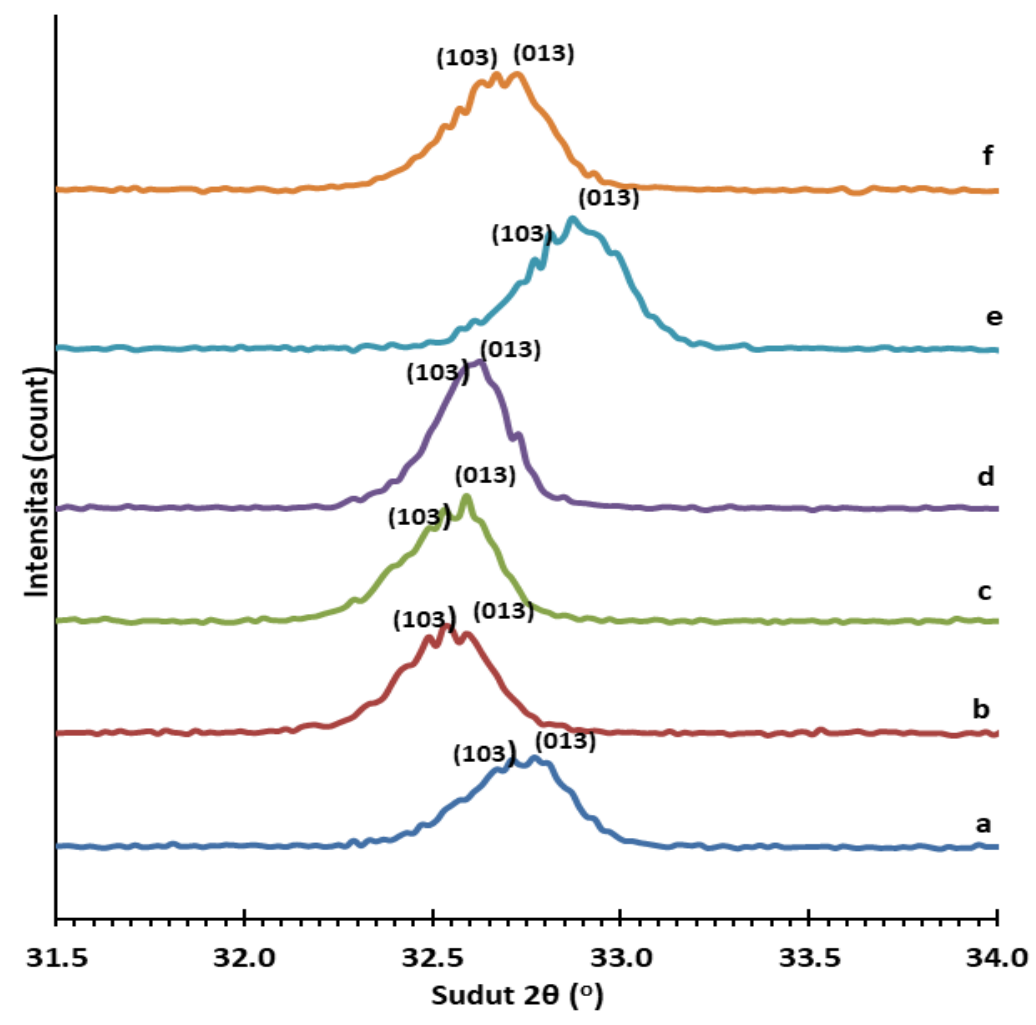

Gambar 3. Puncak difraksi dari bidang (013) dan (103) dari $\mathrm{Gd}_{0.85} \mathrm{La}_{0.15} \mathrm{Ba}_{2-}$ ${ }_{\mathrm{x}} \mathrm{Sr}_{\mathrm{x}} \mathrm{Cu}_{3} \mathrm{O}_{7-\delta}$ untuk nilai x: (a) 0,00; (b) 0,05; (c) 0,10; (d) 0,20; (f) 0,30 dan (f) 0,50.

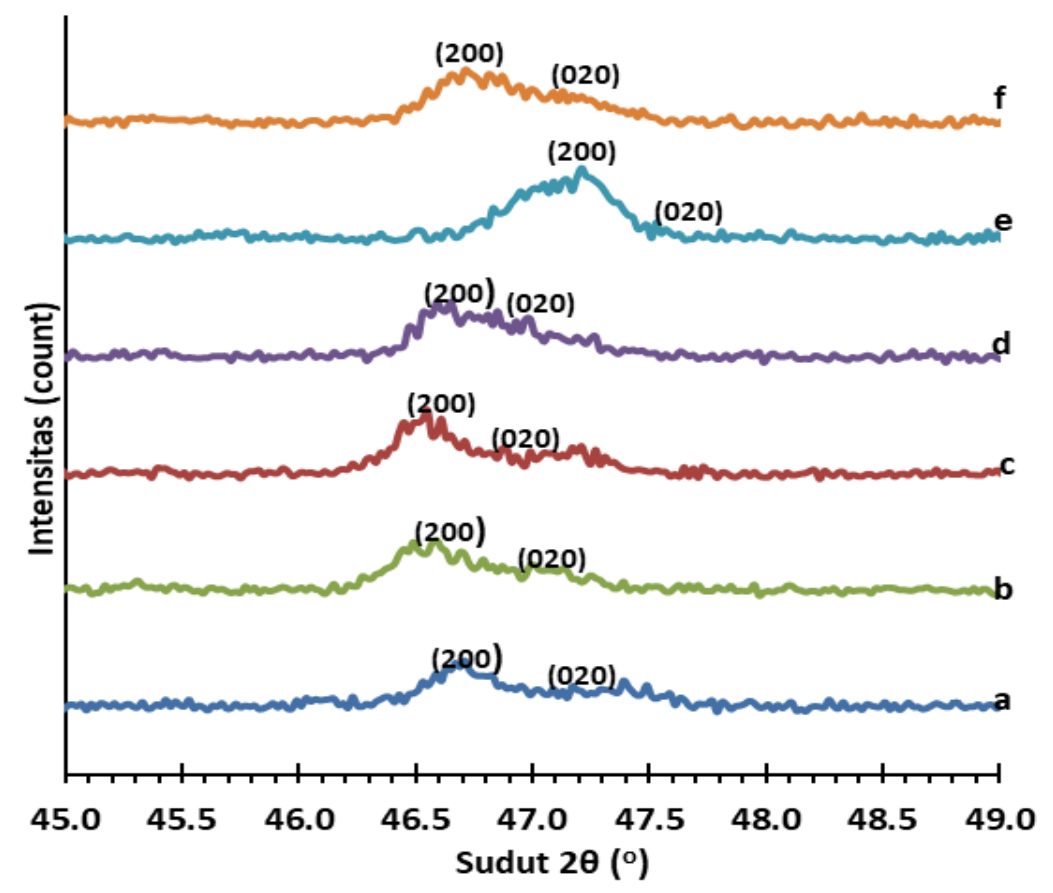

Gambar 4. Puncak difraksi dari bidang (200) dan (020) dari $\mathrm{Gd}_{0.85} \mathrm{La}_{0.15} \mathrm{Ba}_{2-\mathrm{x}} \mathrm{Sr}_{\mathrm{x}} \mathrm{Cu}_{3} \mathrm{O}_{7-\delta}$ untuk nilai x: (a) 0,00; (b) 0,05; (c) 0,10; (d) 0,20; (f) 0,30 dan (f) 0,50. 


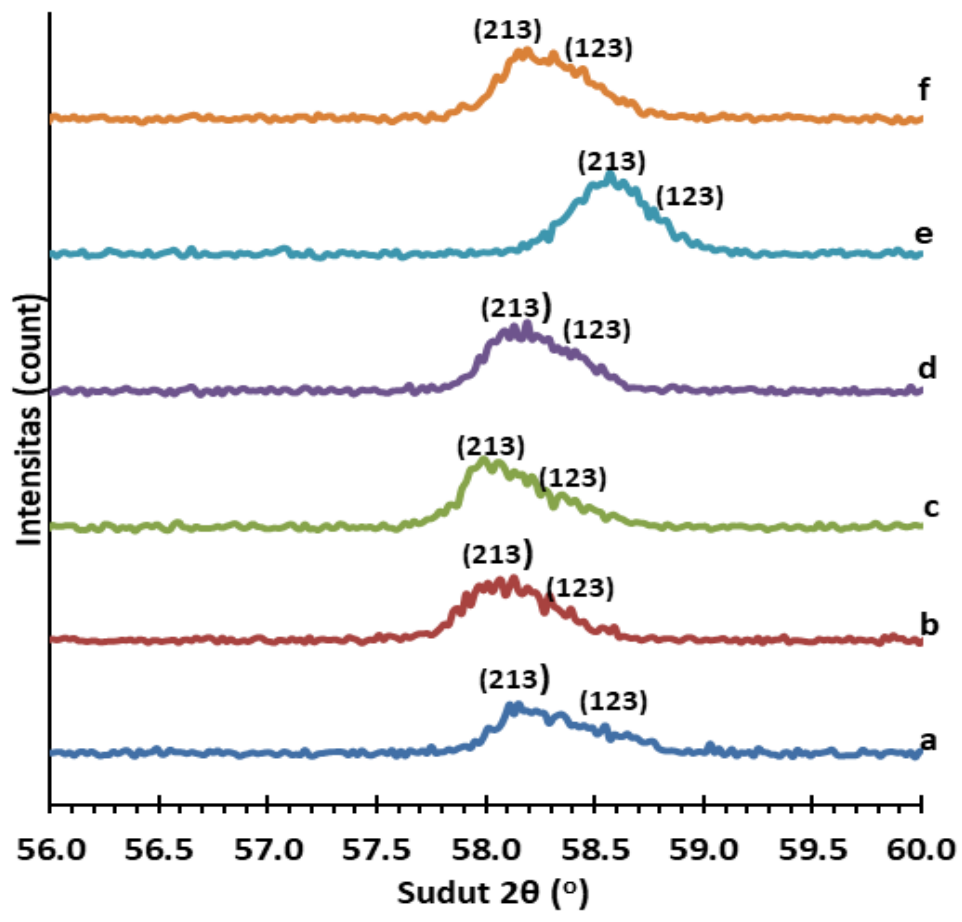

Gambar 5. Puncak difraksi bidang (213) dan (123) dari $\mathrm{Gd}_{0.85} \mathrm{La}_{0.15} \mathrm{Ba}_{2-\mathrm{x}} \mathrm{Sr}_{\mathrm{x}} \mathrm{Cu}_{3} \mathrm{O}_{7-\delta}$ untuk nilai x: (a) 0,00; (b) 0,05; (c) 0,10; (d) 0,20; (f) 0,30 dan (f) 0,50.

Dengan metode Rietveld menggunakan software Rietica dapat diperoleh nilai parameter kisi seperti ditunjukkan pada kolom 2 - 4 pada Tabel 1. Dari nilai parameter kisi tersebut dan dengan menggunakan persamaan (1) dihitung nilai Orthorombic Splitting, hasilnya ditunjukkan pada kolom 5 pada Tabel 1. Sementara itu, posisi puncak-puncak difraksi dari bidang (hkl) utama (Gambar 3-5) ditunjukkan pada Tabel 2.

Tabel 1. Parameter kisi dan nilai Orthorombic Splitting pada masing-masing sampel.

\begin{tabular}{ccccc}
\hline Kandungan & \multicolumn{3}{c}{ Parameter kisi $(\AA)$} & \multirow{2}{*}{ OS } \\
\cline { 2 - 4 } Sr & $a$ & $b$ & $c$ & \\
\hline 0,00 & 3,8925 & 3,8441 & 11,6456 & 0,6256 \\
0,05 & 3,8966 & 3,8664 & 11,7116 & 0,3890 \\
0,10 & 3,8997 & 3,8629 & 11,7114 & 0,4741 \\
0,20 & 3,8908 & 3,8638 & 11,6833 & 0,3482 \\
0,30 & 3,8685 & 3,8429 & 11,5677 & 0,3320 \\
0,50 & 3,8831 & 3,8538 & 11,6753 & 0,3787 \\
\hline
\end{tabular}

Tabel 2. Posisi sudut puncak difraksi bidang $(h k l)$ utama dari tiga daerah sudut difraksi.

\begin{tabular}{ccccccc}
\hline \multirow{2}{*}{\begin{tabular}{c} 
Variasi \\
\cline { 2 - 6 } Sr
\end{tabular}} & $(103)$ & $(013)$ & $(200)$ & $(020)$ & $(213)$ & $(123)$ \\
\hline 0,00 & 32,584 & 32,759 & 46,628 & 47,250 & 58,151 & 58,551 \\
0,05 & 32,436 & 32,567 & 46,575 & 46,960 & 57,983 & 58,231 \\
0,10 & 32,423 & 32,582 & 46,536 & 47,006 & 57,960 & 58,262 \\
0,20 & 32,501 & 32,619 & 46,649 & 46,995 & 58,079 & 58,302 \\
0,30 & 32,765 & 32,878 & 46,933 & 47,266 & 58,487 & 58,702 \\
0,50 & 32,546 & 32,673 & 46,747 & 47,124 & 58,198 & 58,440 \\
\hline
\end{tabular}

Selanjutnya, dari Tabel 2 dapat ditentukan jarak pisah sudut puncak difraksi antara dua bidang (hkl) terdekat hasil pengukuran, seperti ditunjukkan pada Tabel 3. Dengan menggunakan persamaan (2), (3) 
dan (4) dapat dihitung jarak pisah $\Delta 2 \theta$ antara sudut puncak difraksi dari dua bidang (hkl) terdekat, hasilnya seperti ditunjukkan pada Tabel 4.

Tabel 3. Jarak pisah sudut puncak difraksi dari dua bidang (hkl) hasil pengukuran dari difraktogram $\left(\mathrm{D}^{\circ}\right)$ : antara bidang (103) dan (013), (020) dan (200), (123) dan (213).

\begin{tabular}{cccc}
\hline \multirow{2}{*}{ Variasi Sr } & \multicolumn{3}{c}{ Jarak pisah sudut $(\mathrm{D})\left(^{\circ}\right)$} \\
\cline { 2 - 4 } & $\mathrm{D}(103)-(013)$ & $\mathrm{D}(020)-(200)$ & $\mathrm{D}(123)-(213)$ \\
\hline 0,00 & 0,211 & 0,622 & 0,400 \\
0,05 & 0,131 & 0,385 & 0,248 \\
0,10 & 0,159 & 0,470 & 0,302 \\
0,20 & 0,118 & 0,346 & 0,223 \\
0,30 & 0,113 & 0,333 & 0,215 \\
0,50 & 0,127 & 0,377 & 0,242 \\
\hline
\end{tabular}

Tabel 4. Jarak pisah sudut dua puncak difraksi bidang $(h k l)$ hasil perhitungan $\left(\Delta 2 \theta^{\circ}\right)$ dengan menggunakan persamaan (2), (3), (4) dan nilai OS/10.

\begin{tabular}{|c|c|c|c|c|}
\hline \multirow{2}{*}{$\begin{array}{c}\text { Variasi } \\
\mathrm{Sr}\end{array}$} & \multicolumn{3}{|c|}{ Jarak pisah sudut $\Delta 2 \theta^{\circ}$} & \multirow{2}{*}{$\mathrm{OS} / 10$} \\
\hline & $\Delta 2 \theta^{\circ}(103)-(013)$ & $\Delta 2 \theta^{\circ}(020)-(200)$ & $\Delta 2 \theta^{\circ}(123)-(213)$ & \\
\hline 0,00 & 0,2006 & 0,6221 & 0,3840 & 0,6256 \\
\hline 0,05 & 0,1432 & 0,4003 & 0,2640 & 0,3890 \\
\hline 0,10 & 0,1650 & 0,4694 & 0,3120 & 0,4741 \\
\hline 0,20 & 0,1320 & 0,3378 & 0,2348 & 0,3482 \\
\hline 0,30 & 0,1000 & 0,3366 & 0,2160 & 0,3320 \\
\hline 0,50 & 0,1200 & 0,3824 & 0,2406 & 0,3787 \\
\hline
\end{tabular}

Dari Tabel 3 dapat dibuat grafik jarak pisah sudut puncak difraksi dari dua bidang (hkl) hasil pengukuran dari difraktogram $\left(\mathrm{D}^{\circ}\right)$ terhadap kandungan $\mathrm{Sr}$ seperti ditunjukkan pada Gambar 6 . Sementara itu, dari Tabel 4 dapat dibuat grafik grafik jarak pisah sudut puncak difraksi dari dua bidang (hkl) hasil perhitungan dengan persamaan (2), (3) dan (4) terhadap kandungan Sr seperti ditunjukkan pada Gambar 7.

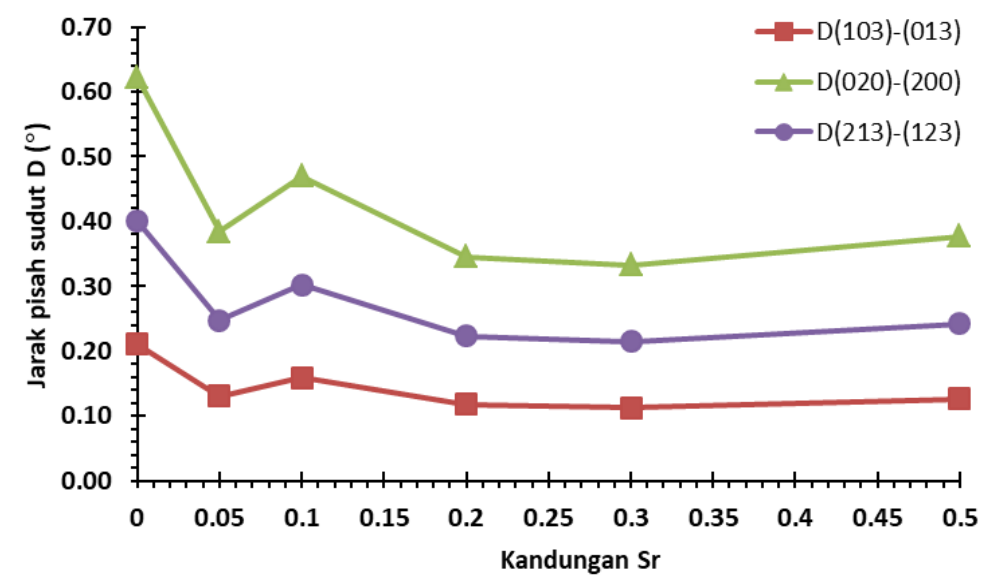

Gambar 6. Jarak pisah sudut puncak difraksi dari dua bidang (hkl) hasil pengukuran dari difraktogram. 


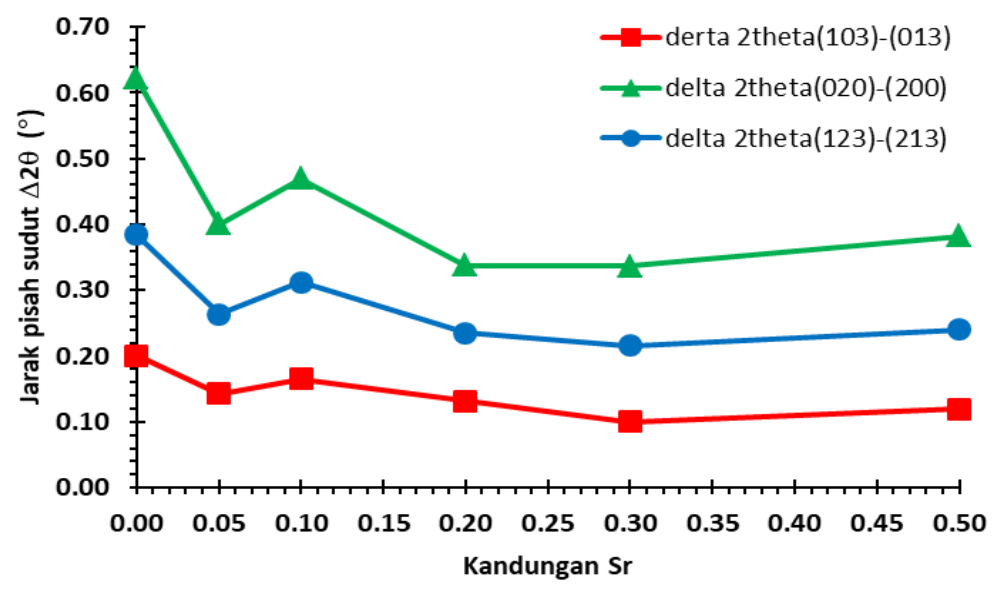

Gambar 7. Jarak pisah sudut puncak difraksi dari dua bidang (hkl) hasil perhitungan dengan menggunakan persamaan (2), (3), dan (4).

Tampak dari Gambar 6 dan Gambar 7 pola perubahan jarak pisah antara dua bidang difraksi terhadap kandungan $\mathrm{Sr}$ adalah serupa. Ini menunjukkan bahwa persamaan (2), (3) dan (4) dapat digunakan sebagai pendekatan untuk menentukan jarak pisah dari dua puncak dari difraksi bidang hkl terdekat. Bila diperhatikan nilai jarak pisah $\mathrm{D}(020)$ - (200) pada Tabel 3, $\Delta 2 \theta(020)$ - (200) dan OS pada Tabel 4 dibagi dengan 10, tampak nilainya hampir sama. Jika dibuat grafik ketiga parameter tersebut terhadap kandungan Sr diperoleh grafik seperti Gambar 8. Tampak ketiganya memperlihatkan pola yang sama (ketiga parameter berimpitan berhimpitan satu sama lain) seiring dengan bertambahnya kandungan Sr. Dengan demikian terdapat indikasi bahwa jarak pisah antara puncak difraksi dari dua bidang (hkl) terdekat pada puncak-puncak difraksi utama dari spektrum XRD, persamaan (2) yang dibuat oleh Yossevof et al. [5] dapat digunakan sebagai indikator dari keorthorhombikan struktur kisi dari senyawa senyawa $\mathrm{Gd}_{0,85} \mathrm{La}_{0,15} \mathrm{Ba}_{2-\mathrm{x}} \mathrm{Sr}_{\mathrm{x}} \mathrm{Cu}_{3} \mathrm{O}_{7-\delta}$.

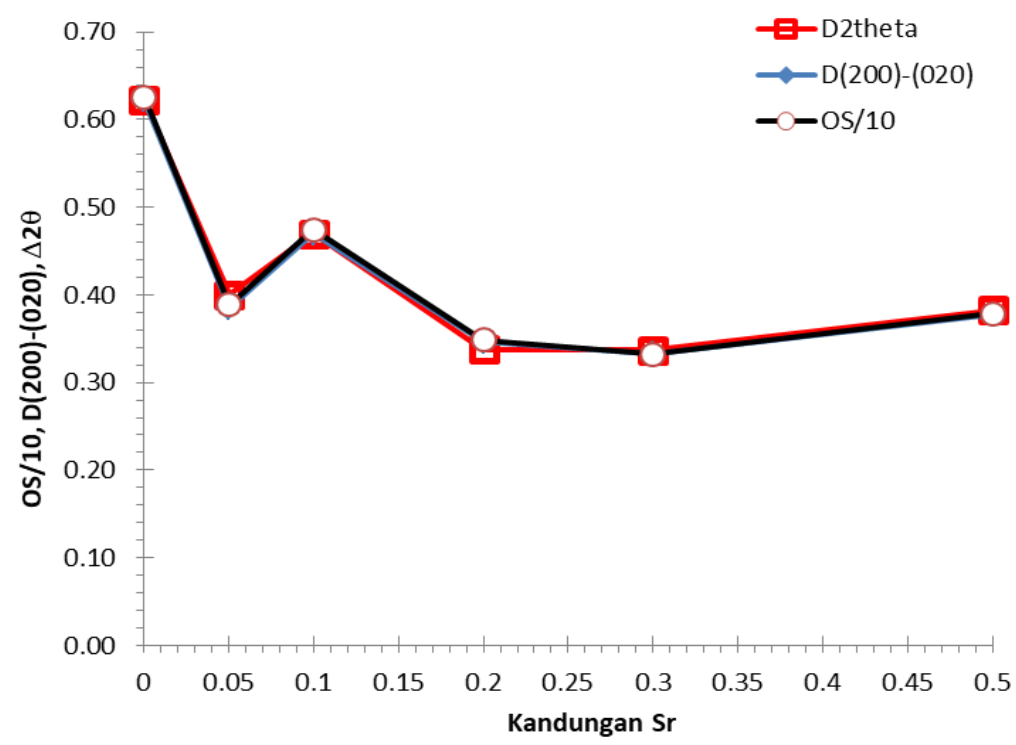

Gambar 8. Pola perubahan jarak pisah D, $\Delta 2 \theta$ dan OS/10.

\section{Kesimpulan}

Telah dilakukan pengukuran dan perhitungan jarak pisah antara sudut puncak difraksi dari dua bidang (hkl) terdekat pada puncak-puncak difraksi utama pada spektrum XRD dari fase $\mathrm{Gd}_{0,85} \mathrm{La}_{0,15} \mathrm{Ba}_{2-}$ ${ }_{x} \mathrm{Sr}_{\mathrm{x}} \mathrm{Cu}_{3} \mathrm{O}_{7-\delta}$. Diperoleh bahwa, dengan bertambahnya kandungan $\mathrm{Sr}$ pola perubahan nilai jarak pisah sudut puncak difraksi bidang (hkl) terdekat hasil dari pengukuran dan perhitungan sama dengan pola perubahan nilai keorthorhombikannya (orthorhombicity). Hasil pengukuran dan perhitungan nilai jarak pisah antara sudut puncak difraksi untuk bidang (020) dan (200) hampir sama dengan sepersepuluh dari 
nilai keorthorhombikan (OS/10). Oleh karena itu, dapat diambil kesimpulkan bahwa nilai jarak pisah antara sudut puncak difraksi dari dua bidang (hkl) terdekat pada puncak-puncak difraksi utama pada spektrum XRD fase $\mathrm{Gd}_{0,85} \mathrm{La}_{0,15} \mathrm{Ba}_{2-\mathrm{x}} \mathrm{Sr}_{\mathrm{x}} \mathrm{Cu}_{3} \mathrm{O}_{7-\delta}$ dapat digunakan sebagai indikator keorthorhombikan struktur kristal $\mathrm{GdBa}_{2} \mathrm{Cu}_{3} \mathrm{O}_{7-\delta}$.

\section{Ucapan terima kasih}

Saya sampaikan ucapan terima kasih kepada FMIPA Universitas Udayana yang telah memberikan dukungan dana untuk penelitian ini. Demikian juga kepada Laboratorium Fisika Material Program Studi Fisika FMIPA Universitas Udayana atas fasilitas yang diberikan sehingga penelitian ini dapat dilakukan dengan baik.

\section{Pustaka}

[1] M. Aravinda M. Kini, U. Geiser, Huey-Chuen I. Kao, K. Douglas Carlson, Hau H. Wang, Marilyn, R. Monaghan, J.M. Williams, High- T, Superconductors: Selective Preparation and Characterization

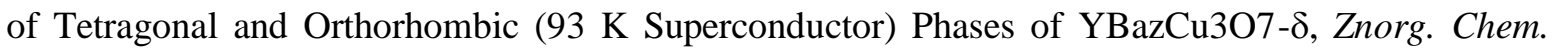
Vol. 26, 1987, pp. 1834-1836.

[2] P. Benzi, E. Bottizzo, N. Rizzi, Oxygen Determination From Cell Dimensions in YBCO Superconductors, Journal of Crystal Growth, Vol. 269, 2004, pp. 625-629.

[3] W. Wong-Ng, L. P. Cook, H. B. Su, M. D. Vaudin, C. K. Chiang, D. R. Welch, E. R. Fuller, Jr, Z. Yang, L. H. Bennett, Phase Transformations in the High Tc Superconducting Compounds, $\mathrm{Ba}_{2} \mathrm{RCu}_{3} \mathrm{O}_{7-\delta}(\mathrm{R}=\mathrm{Nd}, \mathrm{Sm}, \mathrm{Gd}, \mathrm{Y}, \mathrm{Ho}$, and Er), J. Res. Natl. Inst. Stand. Technol., Vol. 111, 2006, pp. 41-55.

[4] I-Wei Chen, S.J. Keating, C.Y. Keating, X. Wu, J. Xu, P.E. Reyes-Morel, and T.Y. Tien, Structural Behavior and Superconductivity of $\mathrm{YBa}_{2} \mathrm{Cu}_{3} \mathrm{O}_{\mathrm{x}}$, Solid State Communications, Vol. 63 (11), 1987, pp. 997-1001.

[5] P. Yossefov, G.E. Shter, G.M. Reisner, A. Friedman, Y. Yeshurun, G.S. Grader, Relationship of Solubility Parameter (x), Powder Properties And Phase Formation in the $\mathrm{Nd}_{1+\mathrm{x}} \mathrm{Ba}_{2-\mathrm{x}} \mathrm{Cu}_{3} \mathrm{O}_{6.5+\mathrm{x} / 2+\delta}$ system, Physica C, 1997, Vol. 275, pp. 299-310.

[6] C. Rial, E. Mora, M. A. Alario-Franco, U. Amador, N.H. Andersen, Structural and superconducting properties of $\mathrm{La}_{2-\mathrm{x}} \mathrm{Nd}_{\mathrm{x}} \mathrm{CuO}_{4+\mathrm{y}}(0 \leq \mathrm{x} \leq 0.5)$ prepared by room temperature chemical oxidation, Physica C, Vol. 281, No.2, pp. 781-782.

[7] F. Licci, A. Gauzzi., M. Marezio, G. P. Radaelli, R.C. Masini, C. Chaillout-Bougerol, Structural and Electronic Effects of Sr Substitution for Ba in $\mathrm{Y}\left(\mathrm{Ba}_{1-\mathrm{x}} \mathrm{Sr}_{2}\right)_{2} \mathrm{Cu}_{3} \mathrm{O}_{\mathrm{w}}$ at Varying w, Physical Review B, 1998, Vol. 58, No. 22, pp. 209-217.

[8] I K. Wahyu S. P., Sintesis Senyawa $\mathrm{Gd}_{0.85} \mathrm{La}_{0.15} \mathrm{Ba}_{2-\mathrm{x}} \mathrm{Sr}_{\mathrm{x}} \mathrm{Cu}_{3} \mathrm{O}_{7-\delta}$ Dengan Variasi Molar $0<\mathrm{x} \leq$ 0,50 Menggunakan Metode Reaksi Padatan Dengan Pencampuran Basah (Wet Mixing), Skripsi, PS Fisika FMIPA Universitas Udayana, 2020 (in press).

[9] M. Sumadiyasa, I G A. Putra Adnyana, N. Wendri, P. Suardana, Synthesis and Characterization of GLBCO-123 Phase: $\mathrm{Gd}_{1-\mathrm{x}} \mathrm{L}_{\mathrm{x}} \mathrm{Ba}_{2} \mathrm{Cu}_{3} \mathrm{O}_{7-\delta}(\mathrm{x}=0.0$ - 0.5), Journal of Materials Science and Chemical Engineering, 2017, Vol.5, pp. 49-57. https://doi.org/10.4236/msce.2017.511005.

[10] M. Sumadiyasa, I G A. Putra Adnyana, I G A. Widagda, W G Suharta, Study synthesis of ( La $_{1-}$ $\left.{ }_{\mathrm{x}} \mathrm{Gd}_{\mathrm{x}}\right) \mathrm{Ba}_{2} \mathrm{Cu}_{3} \mathrm{O}_{7-\delta}$ Superconductors at Low Temperature, Journal of Physics, Conference Series, 2016, Vo. 725, 012001. https://doi.org/10.1088/1742-6596/725/1/012001. 